\title{
New players in entrepreneurial finance and why they are there
}

\author{
Joern H. Block • Massimo G. Colombo • \\ Douglas J. Cumming • Silvio Vismara
}

Accepted: 01 December 2016/Published online: 17 January 2017

(C) The Author(s) 2017. This article is published with open access at Springerlink.com

\begin{abstract}
The landscape for entrepreneurial finance has changed strongly over the last years. Many new players have entered the arena. This editorial introduces and describes the new players and compares them along the four dimensions: debt or equity, investment goal, investment approach, and investment target. Following this, we discuss the factors explaining the emergence of the new players and group them into supply- and demand-side factors. The editorial gives researchers and practitioners orientation about recent developments in entrepreneurial finance and provides avenues for relevant and fruitful further research.
\end{abstract}

\author{
J. H. Block $(\bowtie)$ \\ University of Trier, Trier, Germany \\ e-mail: block@uni-trier.de \\ J. H. Block \\ Erasmus University Rotterdam, Rotterdam, the Netherlands \\ M. G. Colombo \\ Politecnico di Milano, Milan, Italy \\ e-mail: massimo.colombo@polimi.it

\section{J. Cumming} \\ Schulich School of Business, York University, Toronto, Canada \\ e-mail: douglas.cumming@gmail.com

\section{S. Vismara} \\ University of Bergamo, Bergamo, Italy \\ e-mail: silvio.vismara@unibg.it \\ S. Vismara \\ University of Augsburg, Augsburg, Germany
}

Keywords Entrepreneurial finance $\cdot$ SME financing . Financing instruments $\cdot$ New players $\cdot$ Trends . Crowdfunding

JEL classification $\mathrm{L} 26 \cdot \mathrm{G} 23 \cdot \mathrm{G} 24$

\section{Introduction}

Young innovative firms play a key role in modern knowledge-based economies because they are an important source of new jobs, radical innovations, and productivity growth, as well as a disciplining device for the behavior of established firms (Block et al. 2016). Unfortunately, these firms often suffer from financing constraints, which limit their growth and threaten their survival (Brown and Earle 2015; Carpenter and Petersen 2002; Cosh et al. 2009). A wide literature has addressed the theme of financial constraints for young innovative firms. Lack of internal cash flows and collaterals, as well as asymmetric information and agency problems, are the main reasons for the difficulties in raising external funding (see Hall and Lerner (2010) for a summary of the literature). The entrepreneurial finance literature addresses these problems and investigates ways how young innovative firms can access capital for financing growth, innovation, and internationalization.

The landscape for entrepreneurial finance, however, has changed over the last years. ${ }^{1}$ Many new players

\footnotetext{
${ }^{1}$ See Kraemer-Eis et al. (2016) for an overview of the European
} landscape for entrepreneurial finance. 
such as crowdfunding, accelerators, and family offices have entered the arena, and several new entrepreneurial financing instruments such as peer-to-peer business lending and equity-like mezzanine financing have been introduced. These new players and instruments have emerged, among others, because of the difficulties faced by entrepreneurs and early-stage new ventures in raising funds, especially in the wake of the 2008/2009 financial crisis. Other reasons comprise increased technological opportunities, changed requirements in firms' product markets, globalization, and regulatory changes. Moreover, the difficulties firms encounter in raising seed and start-up capital play an increasingly important role in the policy agenda of local, national, and international governmental institutions, as is documented by the measures included in the Horizon 2020 and COSME projects funded by the European Commission.

In less than a decade, these new players and instruments have spread across developed and emerging countries, helping many innovative businesses in raising capital. In addition to that, governments around the world are increasingly considering these new players and instruments as fundamental mechanisms to alleviate the financing difficulties of entrepreneurial firms. Despite this rapid growth, however, the academic literature on most of the recent trends in entrepreneurial finance is still in its infancy; hence, there is ample room for further inquiring and a high need for the special issue "new trends in entrepreneurial finance" from both a practical and theoretical perspective.

This editorial to the special issue compares the new players along the four dimensions (1) debt or equity, (2) investment goal, (3) investment approach, and (4) investment target. Following this introduction and comparison of new players, we discuss the underlying factors or reasons explaining their emergence. We group these factors or reasons into demand-side and supply-side factors. After the comparison of the new players and the discussion of the factors or reasons behind their emergence, the editorial provides a brief overview of the content of the special issue and introduces the 10 articles included in the special issue. When possible, we establish a link between the respective article and our overview of new players. The editorial has the goal to give researchers in the area of entrepreneurial finance orientation about recent developments and thereby provide avenues for relevant and fruitful further research.

The remainder of the editorial is divided into four sections. Section 2 introduces and compares the new players in entrepreneurial finance, Section 3 discusses the underlying trends, Section 4 summarizes the special issue papers, while Section 5 concludes and discusses relevant areas for further research.

\section{An overview and comparison of new players in entrepreneurial finance}

Venture capital (VC) and business angel (BA) financing have traditionally been advocated as important sources of financing for young innovative firms that find it difficult to access bank or debt finance. However, the market and landscape for entrepreneurial finance has changed over the last years. Several new players have emerged, and there has been an increasing presence of other players that have traditionally not had a major role in the market. These players are very heterogeneous and include players as diverse as family offices, the crowd, and venture debt funds. Some of these new players value not only financial goals but are also interested in non-financial goals. These non-financial goals comprise social goals in case of social venture funds, strategic and technological goals in case of corporate venture capital (CVC) firms, political goals in case of governmentsponsored funds, and product-oriented and community-building goals in case of reward-based crowdfunding.

The new players have not only brought a variety of new investment goals but have also introduced new investment approaches, valuation methods or measures, and business models of entrepreneurial financing. As, for example, non-financial goals have become more important, new valuation models or measures have been developed taking into account non-financial goals in the selection of investment targets. Consider, for example, the social return on investment (SROI) measure, which aims to determine the (social) impact of social ventures. For many of the new players, value creation is not only limited to provide financing to promising firms but also includes the provision of value added services, such as management and technological support, and more generally the provision of advice, as well as network access. These active, hands-on investment approaches are not only limited to $\mathrm{VC}$ firms and BAs, who were always following this approach, but are also used by some of the new players such as incubators and accelerators, university-managed 
funds, and sometimes even backers of reward-based crowdfunding campaigns.

Next to the emergence of the new players, the whole environment of entrepreneurial finance has changed. The median pre-money valuation of young companies is rising into new historical heights, especially in later-stage financing. This can be seen by an ever increasing club of unicorns (private companies valued $>1$ bn US $\$$ ). This has created rumors of a tech-bubble, as many of these companies are unprofitable or do not have created a sustainable revenue-model for their business. High valuations can also put pressure to founders, as they need to deliver on these expectations. The question is what drives these high valuations and what are the risks associated with them. Many start-ups (especially in the USA) have significant cash-burn rates or are unprofitable. Often, this leads their founders to search for new capital very shortly after their last round of financing. As some exit channels are very difficult to reach (e.g., IPO), the current investors can find themselves in a "lock-in" situation of either providing their start-ups additional capital or risking a bankruptcy.

Overall, the emergence of the new players and their variety of investment goals and investment approaches has made entrepreneurial financing a complex and difficult process. Table 1 provides an overview of the new players and compares them along the four dimensions (1) debt or equity, (2) investment goal, (3) investment approach, and (4) investment target.

Accelerators (and incubators) are organizations that aim to help start-ups with mentorship, advice, network access, and shared resources to grow and become successful (Hallen et al. 2016). Sometimes they also offer physical space and financial resources, which often comes in the form of equity. There exist different types of accelerators and incubators, depending on the services offered, the industry focus, and the owner, which could be a private company or a governmental institution.

Angel networks are networks of BAs who invest together in early-stage high growth ventures (see e.g., Croce et al. (2016) for a recent review). They provide equity and offer management support and network access. As a group, they can provide higher amounts of financing than individual BA investors.
Crowdfunding is an umbrella term used to describe diverse forms of fundraising, typically via the Internet, whereby groups of people pool money to support a particular goal (Ahlers et al. 2015; Moritz and Block 2014)There are four main types of crowdfunding, namely reward-based, donationbased, lending-based, and investment-based (equity) crowdfunding. First, in reward-based crowdfunding project, proponents look for finance from a crowd of backers. The most typical reward to backers is the delivery of a (sometime customized) product or service, which makes this type of crowdfunding somehow similar to financial bootstrapping (i.e., crowdfunders are financed by advance payments that most backers give in exchange for the subsequent delivery of a product or service). Backers may also be offered "ego-boosting" rewards, such as a name plaque, or "community-belonging" rewards, such as the invitations in social events (e.g., the launch party of the project) or the offering of symbolic objects that display support for a project. Project proponents are either individuals or companies. The average amount of finance in a successful campaign is rather limited (in Kickstarter or Indiegogo, the most successful reward-based crowdfunding platforms, around 30 to 40,000 US \$), and on average, one project out of three is successful. Previous studies clearly show that the ability of project proponents to mobilize their social capital, within (Colombo et al. 2015) and outside (Mollick, 2013) the crowdfunding platform, plays a key role for the success of a campaign. Second, proponents in donation-based crowdfunding are individuals or non-governmental organizations raising money for a cause. They typically aim to raise as much as possible and the size of the campaign varies from few hundred euros to millions. Motivation to donate includes charitable giving and social image. Third, lending-based crowdfunding is by far the type of crowdfunding with the largest total raised amount. ${ }^{2}$ It takes a variety of different forms, ranging from peer-to-peer lending (see e.g. Lin et al. 2013) to invoice crowdfunding. Motivations for the crowd to invest are mainly financial as lenders receive fixed interest rates for their loans. Lastly, central to entrepreneurial finance is the fourth type of

\footnotetext{
${ }^{2}$ For example, in 2015, 3.2 billion euro of debt was raised from the crowd by more than 200,000 projects in the European Union (see European Commission 2016).
} 
Table 1 An overview and comparison of new players in entrepreneurial finance

\begin{tabular}{|c|c|c|c|c|c|}
\hline \multirow[t]{2}{*}{ New player } & \multirow[t]{2}{*}{ Debt or equity } & \multirow[t]{2}{*}{ Investment goal } & \multicolumn{2}{|c|}{ Investment approach } & \multirow[t]{2}{*}{ Investment target } \\
\hline & & & $\begin{array}{l}\text { Active or } \\
\text { passive }\end{array}$ & $\begin{array}{l}\text { Non-financial } \\
\text { support }\end{array}$ & \\
\hline $\begin{array}{l}\text { Accelerators (and } \\
\text { incubators) }\end{array}$ & $\begin{array}{l}\text { Depends on type of } \\
\text { accelerator/ in- } \\
\text { cubator }\end{array}$ & $\begin{array}{l}\text { Financial, strategic, political } \\
\text { (depends on type of } \\
\text { accelerator/incubator) }\end{array}$ & Active & $\begin{array}{l}\text { Management } \\
\text { support, training, } \\
\text { network access }\end{array}$ & Early stage start-up \\
\hline Angel networks & Equity & Financial & Active & $\begin{array}{l}\text { Management } \\
\text { support, network } \\
\text { access }\end{array}$ & Early stage start-up \\
\hline \multicolumn{6}{|l|}{ Crowd } \\
\hline - Debt-based & Debt & Financial & Passive & None & $\begin{array}{l}\text { Early stage start-up or } \\
\text { project }\end{array}$ \\
\hline - Donation-based & - & Social & Passive & None & $\begin{array}{l}\text { Social venture or } \\
\text { project }\end{array}$ \\
\hline - Reward-based & - & Product-related & $\begin{array}{l}\text { Passive, } \\
\text { Some- } \\
\text { times } \\
\text { active }\end{array}$ & $\begin{array}{l}\text { Sometimes product } \\
\text { testing }\end{array}$ & $\begin{array}{l}\text { Early stage start-up or } \\
\text { project }\end{array}$ \\
\hline - Equity-based & Equity & Financial & Passive & None & $\begin{array}{l}\text { Early stage start-up or } \\
\text { project }\end{array}$ \\
\hline $\begin{array}{l}\text { Corporate venture } \\
\text { capital }(\mathrm{CVC})\end{array}$ & Equity & $\begin{array}{l}\text { Financial, technological, and } \\
\text { strategic }\end{array}$ & Active & $\begin{array}{l}\text { Management } \\
\text { support, } \\
\text { technology } \\
\text { support }\end{array}$ & $\begin{array}{l}\text { Early and later stage } \\
\text { start-up }\end{array}$ \\
\hline Family offices & Equity & Financial & $\begin{array}{l}\text { Mostly } \\
\text { passive }\end{array}$ & Little & Later stage start-up \\
\hline $\begin{array}{l}\text { Governmental } \\
\text { venture capital } \\
\text { (GVC) }\end{array}$ & Debt or equity & Financial and governmental & $\begin{array}{l}\text { Mostly } \\
\text { passive }\end{array}$ & Little & $\begin{array}{l}\text { Early and later stage } \\
\text { start-up }\end{array}$ \\
\hline $\begin{array}{l}\text { IP-based investment } \\
\text { funds }\end{array}$ & - & Financial & Passive & None & Patents \\
\hline $\begin{array}{l}\text { IP-backed debt } \\
\text { funding }\end{array}$ & Debt & Financial & Passive & & $\begin{array}{l}\text { IP-based start-ups and } \\
\text { established mid- } \\
\text { sized firms }\end{array}$ \\
\hline Mini-bonds & Debt & Financial & Passive & & $\begin{array}{l}\text { Established mid-sized } \\
\text { firms }\end{array}$ \\
\hline $\begin{array}{l}\text { Social venture funds } \\
\text { or social venture } \\
\text { capital }\end{array}$ & Debt and equity & Financial and social & Active & $\begin{array}{l}\text { Management } \\
\text { support, network } \\
\text { access }\end{array}$ & Social ventures \\
\hline $\begin{array}{l}\text { University-managed } \\
\text { or university- } \\
\text { based funds }\end{array}$ & Mostly equity & Financial and university-related & Active & $\begin{array}{l}\text { Management } \\
\text { support, network } \\
\text { access }\end{array}$ & $\begin{array}{l}\text { Academic and student } \\
\text { start-ups }\end{array}$ \\
\hline $\begin{array}{l}\text { Venture debt lenders } \\
\text { or funds }\end{array}$ & Debt & Financial & Passive & None & Later stage start-up \\
\hline
\end{tabular}

crowdfunding, equity-based crowdfunding. Equity crowdfunding is a form of financing in which entrepreneurs make an open call to sell a specified amount of equity or bond-like shares in a company on the Internet. The open call and investments take place on an online platform that provides the means for the transactions. The average size of campaigns in the UK platforms Crowdcube and Seedrs is about 250 thousand pounds (Vismara 2016). The motivation to invest is to realize a financial return. Vismara (2016) finds indeed that 
offering rewards to investors does not increase the probability of success of equity crowdfunding campaigns. Relatedly, in a survey of investors in this type of crowdfunding, Cholakova and Clarysse (2015) find that non-financial motives play no significant role in their investment decisions.

Corporate venture capital (CVC) refers to investments by large, established firms into start-ups or growth firms. Instead of acquiring ventures and integrating them into their own organization, large incumbents like Intel, Google, or Johnson \& Johnson take a minority stake in innovative young firms, which remain independent, and help them further develop their promising technologies and markets. CVC investors provide equity and next to financial returns are also interested in strategic goals such as access to new technology and/or new markets or customer segments. CVC investors tend to be more patient investors than independent $\mathrm{VC}$ investors (IVC), and often syndicate with these latter, even if the impact of syndicated deals on the performance of investee companies (as measured e.g., by time to IPO or increase in total factor productivity, see Colombo and Murtinu 2016) seem to be less positive than those of stand-alone deals. CVC investors have been shown to invest either in later or earlier stage ventures, with their inclination to early stage deals depending on the institutional characteristics of the entrepreneurial finance ecosystem in different countries. In particular, Katila et al. (2008) show that in the USA, new ventures prefer to postpone the formation of CVC ties to later stages, so as to better protect their technology. Accordingly, CVC investors often invest in later rounds in companies backed by independent VC investors. Conversely, in their replication study, Colombo and Shafi (2016) highlight that the pattern of CVC investments in the European Union is different: the likelihood of the formation of early stage CVC ties is much higher, as a result of the institutional peculiarities of the European VC market in Europe. CVC has been around since many years (Alvarez-Garrido and Dushnitsky 2016). This form of financing is highly volatile, ranging from 6 to $23 \%$ of the European VC market in the years from 2007 to 2015 (see European Venture Capital Association (EVCA) Annual Reports). Some organizations invest in $\mathrm{VC}$ due to an increasing fear of being disrupted by innovative start-ups. However, CVCs are less autonomous relative to limited partnership VCs, and this lack of autono-my has led to programs being scaled back and canceled among some organizations at different points in time when strategic objectives or staff change. Further, there are compensation differentials across CVCs and limited partnership VCs, which can exacerbate the instability of CVCs.

Families owning large firms increasingly install family offices as intermediaries to manage their wealth (Zellweger and Kammerlander 2015). Thus, instead of owning the firm directly, the family bundles its ownership shares into a family office and only has an indirect ownership share in the firm. This way, conflicts within the group of family owners can be reduced, a professional wealth management is introduced, and flexibility is increased both for the firm and the family. Such family offices increasingly also invest in growth ventures and have evolved into an important player in the market for entrepreneurial finance. The EVCA estimates their share in the market for the financing of growth ventures to be about $1-5 \%$ over the years from 2007 to 2015 . Family offices usually provide equity, have primarily financial goals, and are considered long-term investors.

Many governments have set up programs that seek to foster VC financing, through the establishment of Governmental Venture Capital (GVC) funds, with the aim to alleviate the financial gap problem as well as at the same time to pursue investments that will yield social payoffs and positive externalities to the society. Governments may have various intentions and objectives when setting up these funds. To the extent that these governmental objectives differ, there is heterogeneity in the types of firms that the GVCs invest, in the effort that they devote to their investee firms, and, ultimately, in the efficacy of their investments (Colombo et al. 2016). The success of a GVC program also depends on the institutional environment in which it operates, which is typically poor in less developed areas. This result is in line with the idea that there need to be a good match between "smart money" and "smart places". This affects primarily the performance of GVCs aimed at regional development and localized job creation rather than those that support the development of young high-tech industries. The effectiveness of GVC programs depends largely on their design and aims. With regard to direct public intervention, there is heterogeneity in the type of allocation of governmental funds to GVCs. Allocation types can be classified into three categories: direct public funds, hybrid private-public funds, and funds-of-funds. Direct public funds include investments through government- 
supported VC-like schemes, often with the aim of facilitating the development of a $\mathrm{VC}$ industry within a region or industry. Due to problems related to a lack of skills or crowding-out issues, some of these programs have been modified to include co-investments with private investors. Scholarly evidence indicates that this is a sound decision. For example, Bertoni and Tykvova (2015) document a very positive innovation impact of GVC investments in European pharma and biotech start-ups, but only when the GVC investor enters a syndicate led by a private investor. When GVC investors invest on a stand-alone basis, this positive effect vanishes. Lastly, government support can take the form of funds-offunds, which invest in other investment funds rather than investing directly into companies, with the European Investment Fund being a notable example.

IP-based investment funds invest into intellectual property (IP), mostly patents (Gredel et al. 2012). This way, innovative firms or investors can monetarize their IP and use the funds generated to grow their venture. Thus, IP-based investment funds neither provide equity nor debt, but acquire intellectual assets of a company.

IP-backed debt funding allows firms to exploit the economic value of their IP to obtain loans from banks or other financial institutions (Fischer and Ringler 2014). IP rights can indeed be exploited as a source of capital collateralized by the stream of revenues deriving from licensing or royalty agreements, which typically involve portfolios of copyrights or patents. Although these instruments involve high structuring costs, they can be an important component in the funding processes of innovative start-ups.

Mini-bonds are public bonds issued in special SME bond segments (Mietzner et al. 2017). They were used as a financing instrument by SMEs or "Mittelstand"firms in the aftermath of the financial crisis where banks were either unwilling or unable to provide debt financing. Mini-bonds reflect also the desire by firms to decrease their dependence on bank financing.

Social venture capital funds provide seed-funding to for-profit social enterprise. The funding can come in both debt and equity, and the goal is to achieve a reasonable financial return while also delivering social impact. The latter is what it distinguishes from traditional venture capital financing focusing on simple financial return.

University-managed or university-based funds have recently been launched, mainly to support ideas from university faculty, staff, and alumni. As far as early-stage technology developed in labs is not close to the market, universities need to fund research internally. These funds are important for getting the technology ready to hand it over to a development partner from the private sector.

Venture debt lenders or funds are specialized financial institutions at the intersection of venture capital and traditional debt. They provide loans to start-ups, but unlike traditional bank, financing do not require securities or positive cash flows from start-ups. De Rassenfosse and Fischer (2016) estimate the size of the US venture debt market at about $\$ 3$ billion per year. Internationally, there is little relation between institutional factors such as legal conditions and venture debt returns (Cumming and Fleming 2013; Cumming et al. 2016). However, returns to venture debt funds are closely related to firm-specific proxies for borrower risk (Cumming and Fleming 2013). Also, returns are significantly affected by market conditions such as the VIX index, and whether or not the debt issue is a primary or secondary issuance (Cumming et al. 2016).

\section{Factors explaining the emergence of new players}

Following the introduction of the new players in entrepreneurial financing, we now try to understand the underlying factors that lead to their emergence. We distinguish between supply-side and demand-side factors.

\subsection{Supply-side factors}

\subsubsection{Economic and financial crisis related factors}

Supply-side factors refer to the supply side of entrepreneurial financing and comprise various types of factors, some of which can be linked to the 2008/2009 financial crisis and the economic crisis that followed. As a reaction to the financial crisis, the regulation of financial institutions has intensified with a strong focus on banks. Examples of these regulations include Basel II and III, which increase the minimum capital requirements that a bank has to hold dependent on the riskiness of the loans it has given out. To comply with these intensified regulations, banks had to introduce various risk measures that make small firm financing more complex and expensive. As a result, start-ups and small firms with uncertain and risky business models have little chances to obtain bank financing for their ventures. 
The financial crisis was followed by a severe economic crisis in several EU member states and the USA. As a reaction to the economic crisis, the central banks cut interest rates to stimulate economic activity. The low interest rates made debt financing relatively cheap compared to other sources of entrepreneurial financing, provided that the venture's business model is low risk and that is has enough track record and securities to comply with the intensified risk measures introduced by the banks (see previous paragraph).

The low interest rates also had an effect on investors. They made investments in government and corporate bonds less attractive and have led investors to seek other investment opportunities. This has benefitted, among others, venture capital funds, incubators or crowdfunding providers in their fund raising efforts. This, in turn, increased the chances for innovative, high-risk ventures to receive risk capital.

The tough economic climate and the negative experiences with the dotcom bubble in the year 2000 have led to a decrease in initial public offerings (IPOs). Consider, for example, Germany, where the "Neuer Markt" (the stock market segment for high tech and innovative ventures) closed down in 2001 (Vismara et al. 2012). This collapse along with the negative experiences made by investors has brought the market for IPOs down and created difficulties for risk or venture capital providers to exit their investments. The reduced exit possibilities make it more difficult for risk capital providers like VC funds to collect funds and invest them into start-ups (Block and Sandner 2009).

\subsubsection{Regulation-related factors}

In general, it is well established that countries with stronger regulations enable entrepreneurship and entrepreneurial finance, as regulation can lower the cost of entry and ensure contractual certainty. However, in some cases, the comparative dearth of regulatory enforcement can also positively affect the presence of start-ups. For example, the absence of enforcement of banking regulations has enabled a comparative growth of financial technology (FinTech) start-ups in countries without a major financial center (Cumming and Schwienbacher 2016).

Partially, due to increased regulation on traditional stock markets, off-exchange transactions have been attracting increasingly larger trading volumes. Initially, dark (or blind) pools emerged informally in formal stock exchanges, which would take large buy and sell orders in certain shares and match them, after the close of trading. Later, investment banks and independent operators, such as Liquidnet, started matching orders internally, avoiding transaction fees to stock exchanges.

New exchange platforms that trade pre-IPO shares (or, in general, shares of private firms), such as SecondMarket, the main platform for trading preIPO shares of Facebook, or SharesPost, provide alternative venues to investors and employees for cashing out. The Jumpstart Our Business Startups Act (JOBS Act) in the USA clarified several legal uncertainties regarding the operation of these secondary markets that have reduced the benefits of going public in traditional stock exchanges. Furthermore, Title III of the JOBS Act and the additional rules provided by the Securities and Exchange Commission (SEC) clarify the conditions for crowdfunding platforms offering securities. Whether secondary markets and crowdfunding platforms will be successful ultimately depends on their ability to avoid listing "lemons" on their markets.

Traditional stock markets now offer cheaper possibilities to raise public equity capital. For instance, a large portion of the IPOs on the Toronto second market are accounted for by Capital Pool Companies (CPCs), which are a specialized form of "blind pool" offering (Pandes and Robinson 2014). Meoli et al. (2016) find that firms that graduate from the second to the main market in Toronto outperform VC-backed IPOs by 28.2 percentage points in the 3 years following the listing. Carpentier et al. (2012) document that reverse mergers provide less disclosure to investors than IPOs, suffer from a higher degree of information asymmetry between the firm and its investors, and have poor performance compared with regular IPOs.

\subsubsection{Technology-related factors}

Technology has enabled the emergence of some new players. Consider, for example, the case of rewardbased crowdfunding, peer-to-peer lending, or invoice crowdfunding platforms. These players or financing instruments were only made available by technologies such as the Internet and new ways of communication via social media. As a separate but related matter, FinTech start-ups are currently raising large sums of money, which might have a 
tremendous influence on entrepreneurial finance. Virtual currencies like Bitcoin and their associated technologies (notably distributed ledgers based on blockchain) can change the business models of existing players in entrepreneurial finance and push the new players even further. These technologies provide new ways to assess risk and treat financial information, allow for easier participation of nonprofessional investors in entrepreneurial financing, provide greater liquidity, and reduce monitoring costs of investors, but can also lead to higher contagion risk due to greater connectedness through securitization.

\subsubsection{Policy-related factors}

The creation of functioning markets of entrepreneurial finance has become a priority for many governments around the world and has led to many policy initiatives. The JOBS act in the USA changed a number of laws and regulations making it easier for small firms to conduct an IPO or to collect funds through crowdfunding. Many governments installed GVC funds to complement the market for private VC funding (Leleux and Surlemount 2013 ), which is underdeveloped in many countries outside the USA. Another area of start-up policy concerns subsidized debt financing via state-owned banks and loan guarantee schemes or state subsidies for startups and high-growth firms. Such policy initiatives reduce either the costs of a particular financing instrument or provide direct funding to new ventures through state subsidies.

\subsection{Demand-side factors}

Next to supply-side factors, there also exist demandside factors related to the demands of start-ups, founders, and the business models and markets in which they operate.

\subsubsection{Product market-related factors}

The rise of the Internet and social media as well as the globalization of product markets, have created many so-called "winner-take-all markets." Such markets are characterized by strong network externalities and lead to market situations where only a few firms survive. Consider, for example, Facebook or Google as examples of firms operating in highly concentrated and quasi-monopolistic winner-take-all markets. Start-ups in such markets with business models building on network externalities need to grow fast in order to establish standards and create lock-in situations for customers. This, however, drives up cash-burn rates and the amount of funding needed in early stages of the venture cycle.

The high importance of network externalities increases the value of social networks. Entrepreneurial finance institutions such as venture capital firms or business angels, which can provide network access, gain in importance and can offer start-ups important non-financial resources next to funding. In winnertake-all markets, it is important to be fast and engage with the customer at an early stage. Some forms of crowdfunding like reward-based crowdfunding allow for such early customer contact. It is also a way to test a product with customers and enable a form of customer co-creation. Insofar, crowdfunding reflects a general trend toward more open and flexible innovation processes.

Incumbents and established firms fear being disrupted through innovative technologies and start-ups. That is why they are more open to cooperate and invest in start-ups via instruments such as corporate venture capital and corporate incubators. This, in turn, also has an influence on the supply of entrepreneurial finance (see Section 3.1) and increases the possibilities for innovative start-ups to obtain financing.

Another product market-related factor is the growth of the knowledge economy together with a high importance of IP such as patents, trademarks, and design rights. As firms tend to patent more, IPbased financing instruments such as patent-based investment funds become available and can be an option for IP-based start-ups and growth ventures to fund their operations. Moreover, patents can be used as collateral to obtain debt funding from banks and other financial institutions (Fischer and Ringler 2014).

\subsubsection{Disintermediation}

Financial intermediation has been a subject of considerable study in the finance literature. On the one hand, financial intermediaries are meant to reduce information problems and help to meet demand and 
supply of capital; on the other hand, their activity is obviously costly and may introduce agency conflicts. Financial innovation and disintermediation may have the potential to countervail some aspects of sub-optimal principal-agent problems in conventional financial intermediation. More broadly, the value of intermediation is now questioned as innovations allow to by-pass intermediaries so that the participants at the end of the supply and demand chain (i.e., savers/investors and borrowers/fund raisers) meet directly. For instance, the development of online platforms has created new opportunities for entrepreneurs to raise seed capital and for nonprofessional investors to disintermediate their investments. By easing the manner in which demand for capital meets supply, recent financial innovations are expected to improve the efficiency of financial markets. This encourages direct consumer interfaces and evaluation and seems to tease the consumer into a sense of empowerment or "alternativeness." This affects both equity, with a shift from official stock exchanges to crowdfunding, and debt, from traditional banks to peer-to-peer lending and shadow banking. As noted by the Financial Stability Board (FSB 2015), intermediating credit through non-bank channels can have important advantages and contributes to the financing of the real economy, but such channels can also become a source of systemic risk, especially when they are structured to perform bank-like functions and when their interconnectedness with the regular banking system is strong.

\section{The papers in this special issue}

The goal of the special issue is to increase our understanding of recent trends in entrepreneurial finance. It has a strong focus on crowdfunding ( 5 out of 10 papers), which is a result of a recent explosion of empirical research in this area. Next to crowdfunding, the special issue contains papers about IPOs, BAs, GVCs, minibonds, and participative loans. We will now briefly introduce the main content of the special issue papers and create a link to our discussion of new players and instruments.

First, half of the papers in this special issue study crowdfunding. The theoretical paper by Hornuf and Schwienbacher (2017) is about regulation and equity crowdfunding. In contrast to the traditional "law and finance" view that stronger investor protection is better, they argue that too strong investor protection may harm the development of equity crowdfunding markets. Coherently, in many jurisdictions, securities regulation offers exemptions to prospectus and registration requirements. The paper shows that the optimal regulation depends on the availability of alternative early-stage financing such as venture capital and angel finance. Polzin et al. (2017) use survey data from the Netherlands to distinguish between in-crowd and out-crowd funders in order to test for heterogeneity in their information use. This paper shows that in-crowd investors rely more on information about the project creator than out-crowd investors. Out-crowd investors do not seem to attach more importance to information about the project itself than in-crowd investors. Mohammadi and Shafi (2017) introduce the gender issue in entrepreneurial finance. They investigate whether there are gender-related differences in the behavior of crowdfunding investors in Sweden. They find that female investors are less likely to bid in campaigns from younger teams and in high-tech projects, consistent with a greater risk-aversion of female versus male investors. The geographical aspects of crowdfunding are studied by Guenther et al. (2017) and by Giudici et al. (2017). The former presents evidence of the influence of geographic distance among home country retail, accredited, and overseas investors and venture location in an equity crowdfunding context. Geographic distance is indeed negatively correlated with investment probability for all home country investors, while overseas investors are not sensitive to distance. Giudici et al. (2017) find that the success of crowdfunding projects closely depends on the characteristics of the geographical area where project proponents are located, which creates a local basin of potential backers. Accordingly, they document that the altruism of people residing in the area contributes to an increased likelihood of success of reward-based campaigns in Italy. The strength of this effect depends on the level of social capital in the area.

Three manuscripts of the special issue focus on the provision of external equity finance to entrepreneurial firms. Takahashi (2017) examines affiliation ties and underwriter selection in Japanese IPOs. He finds that the presence of board members in the IPO- 
firms who have worked at a specific bank or its parent company increases the probability of choosing the bank as the lead underwriter. This effect is economically larger than that of lending relationships and remains even if the issuer has no lending and shareholding relationships with the underwriter. Levratto et al. (2017) studies the impact of business angel financing on the performance of firms. They are able to do so by using a dataset of French angel-backed companies, which are compared to two control groups, one randomly selected and another one consisting of similar enterprises. They only found a positive influence of BAs on the performance of firms when using the random sample as a comparison group. Standaert and Manigart (2017) focus their attention on the effect of GVC financing on employment in portfolio companies. Using a sample of companies that benefited from the ARKimedes fund-of-fund in Flanders, they find that companies backed by hybrid independent VC funds show greater employment growth than those backed by hybrid captive or hybrid GVC funds. The financial objectives of hybrid independent VC funds are therefore compatible with the government's objective of employment growth.

The last two papers in this special issue deal with debt. Mietzner et al. (2017) is one of very few studies on mini-bonds. Using a German dataset in the period from 2010 to 2015 , they show that rating agencies can create rating inflation by issuing overly favorable ratings. This creates an opportunity for lower-quality firms to compete for funding. In this environment, high-quality firms have an incentive to use mini-bond underpricing to signal their quality. Martí and Quas (2017) prove the effectiveness of a recent form of government support in Spain, called participative loan, in improving recipient SMEs' access to external financial debt. The positive effect of this program is stronger for smaller firms, or for those operating in high-technology sectors, which suffer more acutely from information asymmetries, and negligible for firms that already received support from other government-supported institutions.

\section{Conclusion and avenues for future research}

To summarize, the markets for entrepreneurial finance have changed rapidly over the last years. Many new players have entered the arena. Scholarly research in entrepreneurial financing appears biased toward certain players and financing instruments such as VC and, more recently, crowdfunding and has neglected others. Examples of neglected new players in entrepreneurial financing are debt venture funds, angel networks, and family offices.

Another neglected area in entrepreneurial finance research is the interplay or interaction between the new players or instruments and the established forms of entrepreneurial financing such as VC or BA financing. Start-ups seeking financing often use several financing instruments simultaneously (Moritz et al. 2016). Most existing entrepreneurial finance research focuses on single financing instruments such as VC or bank financing and does not take a holistic approach where financing instruments are regarded as complements rather than substitutes. For example, it would be intriguing to understand how a new form of financing such as crowdfunding can be used simultaneously with established forms of venture financing such as bank financing or $\mathrm{VC}$. Indeed, there is evidence of growing interest of VCs and BAs in relying on the "wisdom of the crowd" and using crowdfunding campaigns as a testbed for the companies they back (Colombo and Shafi 2017). Research about financing instruments also misses a longitudinal perspective. We know little how using one instrument influences the likelihood to obtain another instrument later on. It is important to understand path dependencies in the process of entrepreneurial financing, e.g., whether VC funding can follow crowdfunding or the other way around. ${ }^{3}$

From a practical perspective, we lack information about whether the new players and their financing instruments are reducing the early stage funding gap in the financing of innovative ventures or whether they merely replace or crowd out existing later-stage financing instruments. A financing gap exists with new technologies that have not proven their commercial applications or usefulness. We do not know much whether and to what degree the new players and their financing instruments help to close this gap.

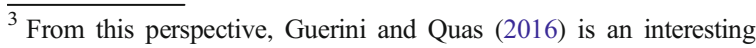
exception. Their longitudinal analysis of the interaction of GVC and private VC investments documents that GVC-backed companies are far more likely to attract private $\mathrm{VC}$ investments than comparable nonVC-backed companies.
} 
Acknowledgements We thank René Andres and Alexandra Moritz for their helpful comments and suggestions on earlier versions of the manuscript.

Open Access This article is distributed under the terms of the Creative Commons Attribution 4.0 International License (http:// creativecommons.org/licenses/by/4.0/), which permits unrestricted use, distribution, and reproduction in any medium, provided you give appropriate credit to the original author(s) and the source, provide a link to the Creative Commons license, and indicate if changes were made.

\section{References}

Ahlers, G. K., Cumming, D., Günther, C., \& Schweizer, D. (2015). Signaling in equity crowdfunding. Entrepreneurship: Theory and Practice, 39(4), 955-980.

Alvarez-Garrido, E., \& Dushnitsky, G. (2016). Are entrepreneurial ventures' innovation rates sensitive to investor complementary assets? Comparing biotech ventures backed by corporate and independent VCs. Strategic Management Journal, 37(5), 819-834.

Bertoni, F., \& Tykvova, T. (2015). Does governmental venture capital spur invention and innovation? Evidence from young European biotech companies. Research Policy, 44(4), 925935.

Block, J., \& Sandner, P. (2009). What is the effect of the financial crisis on venture capital financing? Empirical evidence from US Internet start-ups. Venture Capital-an International Journal of Entrepreneurial Finance, 11(4), 295-309.

Block, J., Fisch, C., \& van Praag, M. (2016). The Schumpeterian entrepreneur: a review of the empirical evidence on the antecedents, behavior, and consequences on innovative entrepreneurship. Industry and Innovation. doi:10.1080 /13662716.2016.1216397.

Brown, J. D., \& Earle, J. S. (2015). Finance and growth at the firm level: evidence from SBA loans. IZA Working Paper No. 9267.

Carpenter, R., \& Petersen, B. (2002). Is the growth of small firms constrained by internal finance? The Review of Economics and Statistics, 84, 298-309.

Carpentier, C., Cumming, D. J., \& Suret, J.-M. (2012). The value of capital market regulation: IPOs versus reverse mergers. Journal of Empirical Legal Studies, 9(1), 56-91.

Cholakova, M., \& Clarysse, B. (2015). Does the Possibility to Make Equity Investments in Crowdfunding Projects Crowd Out Reward-Based Investments? Entrepreneurship Theory and Practice, 39(1), 145-172.

Colombo, M. G., \& Murtinu, S. (2016). Venture capital investments in Europe and portfolio firms' economic performance: independent versus corporate investors. Journal of Economics \& Management Strategy. doi:10.1111 /jems.12170.

Colombo, M. G., \& Shafi, K. (2016). Swimming with sharks in Europe: when are they dangerous and what can new ventures do to defend themselves? Strategic Management Journal, 37(11), 2307-2322.
Colombo, M. G., \& Shafi, K. (2017). When does reward-based crowdfunding help firms obtain external financing? SSRN working paper. http://dx.doi.org/10.2139/ssrn.2785538.

Colombo, M. G., Franzoni, C., \& Rossi Lamastra, C. (2015). Internal social capital and the attraction of early contributions in crowdfunding. Entrepreneurship Theory and Practice, 39(1), 75-102.

Colombo, M. G., Cumming, D. J., \& Vismara, S. (2016). Governmental venture capital for innovative young firms. Journal of Technology Transfer, 41(1), 10-24.

Cosh, A., Cumming, D. J., \& Hughes, A. (2009). Outside entrepreneurial capital. Economic Journal, 119, 1494-1533.

Croce, A., Guerini, M. and Ughetto, E. (2016), Angel Financing and the Performance of High-Tech Start-Ups. Journal of Small Business Management. doi:10.1111/jsbm. 12250.

Cumming, D. J., \& Fleming, G. (2013). Debt investments in private firms: legal institutions and investment performance in 25 countries. Journal of Fixed Income, Summer, 2013, $102-123$.

Cumming, D. J., \& Schwienbacher, A. (2016). Fintech venture capital. SSRN working paper. https://ssrn. com/abstract $=2784797$.

Cumming, D. J., Fleming, G., \& Liu, Z. F. (2016). Private debt: volatility, credit risk, and returns. SSRN working paper. https://ssrn.com/abstract=2609235.

De Rassenfosse, G., \& Fischer, T. (2016). Venture debt financing: determinants of the lending decision. Strategic Entrepreneurship Journal, 10, 235-256.

European Commission. (2016). Crowdfunding in the EU Capital Markets Union. http://ec.europa.eu/finance/generalpolicy/docs/crowdfunding/160428-crowdfunding-study_en. pdf.

Financial Stability Board. (2015). Global shadow banking monitoring report 2015. http://www.fsb.org/2015/11/globalshadow-banking-monitoring-report-2015.

Fischer, T., \& Ringler, P. (2014). What patents are used as collateral? - an empirical analysis of patent reassignment data. Journal of Business Venturing, 29(5), 633-650.

Giudici, G., Guerini, M., \& Rossi-Lamastra, C. (2017). Rewardbased crowdfunding of entrepreneurial projects: the effect of local altruism and localized social capital on proponents' success. Small Business Economics (in press).

Gredel, D., Kramer, M., \& Bend, B. (2012). Patent-based investment funds as innovation intermediaries for SMEs: in-depth analysis of reciprocal interactions, motives and fallacies. Technovation, 9-10, 536-549.

Guenther, C., Johan, S., \& Schweizer, D. (2017). Is the crowd sensitive to distance?-How investment decisions differ by investor type. Small Business Economics (in press).

Guerini, M., \& Quas, A. (2016). Governmental venture capital in Europe: screening and certification. Journal of Business Venturing, 31(2), 175-195.

Hall, B., \& Lerner, J. (2010). The financing of R\&D and innovation. In: Hall, B. H. and N. Rosenberg, Handbook of the Economics of Innovation, Elsevier (April), 609-639.

Hallen, B. L., Bingham, C., \& Cohen, S. (2016). Do accelerators accelerate? The role of indirect learning in new venture development. https://ssrn.com/abstract=2719810.

Hornuf, L., \& Schwienbacher, A. (2017). Should securities regulation promote equity crowdfunding? Small Business Economics (in press). 
Katila, R., Rosenberger, J. D., \& Eisenhardt, K. M. (2008). Swimming with sharks: technology ventures, defense mechanisms and corporate relationships. Administrative Science Quarterly, 53(2), 295-332.

Kraemer-Eis, H., Lang, F., Torfs, W., \& Gvetadze, S. (2016). European Small Business Finance Outlook June 2016. EIF Research \& Market Analysis Working Paper 2016/35.

Leleux, B., \& Surlemont, B. (2003). Public versus private venture capital: seeding or crowding out? A pan-European analysis. Journal of Business Venturing, 18, 81-104.

Levratto, N., Tessier, L., \& Fonrouge, C. (2017). Business performance and angels presence: a fresh look from France 20082011. Small Business Economics (in press).

Lin, M., Prabhala, N. R., \& Viswanathan, S. (2013). Judging borrowers by the company they keep: friendship networks and information asymmetry in online peer-to-peer lending. Management Science, 59(1), 17-35.

Martí, J., \& Quas, A. (2017). A beacon in the night: government certification of SMEs towards banks. Small Business Economics (in press).

Meoli, M., Pandes, J. A., Robinson, M. J., \& Vismara, S., (2016). Can spending time in the minors pay off? SSRN working paper. $h$ ttps://ssrn.com/abstract=2776573.

Mietzner, M., Proells, J., \& Schweizer, D. (2017). Hidden champions or black sheep? The role of underpricing in the German mini-bond market. Small Business Economics (in press).

Mohammadi, A., \& Shafi, K. (2017). Gender differences in the contribution patterns of equity-crowdfunding investors. Small Business Economics (in press).
Mollick, E. (2013). The dynamics of crowdfunding: determinants of success and failure. Journal of Business Venturing, 29(1), 1-16.

Moritz, A., \& Block, J. (2014). Crowdfunding und Crowdinvesting: State-of-the-Art der wissenschaftlichen Literatur. Zeitschrift für KMU und Entrepreneurship, 62(1), 57-89.

Moritz, A., Block, J., \& Heinz, A. (2016). Financing patterns of European SMEs - an empirical taxonomy. Venture Capitalan International Journal of Entrepreneurial Finance, 18(2), 115-148.

Pandes, J. A., \& Robinson, M. J. (2014). Is effective junior equity market regulation possible? Financial Analysts Journal, 70(4), 42-54.

Polzin, F., Toxopeus, H., \& Stam, E. (2017). The wisdom of the crowd in funding. Information heterogeneity and social networks of crowdfunders. Small Business Economics (in press).

Standaert, T., \& Manigart, S. (2017). Government as fund-of-fund and VC fund sponsors: effect on employment in portfolio companies. Small Business Economics (in press).

Takahashi, H. (2017). Affiliation ties and underwriter selection. Small Business Economics (in press).

Vismara, S. (2016). Equity retention and social network theory in equity crowdfunding. Small Business Economics, 46(4), 579-590.

Vismara, S., Paleari, S., \& Ritter, J. R. (2012). Europe's second markets for small companies. European Financial Management, 18(3), 352-388.

Zellweger, T., \& Kammerlander, N. (2015). Family, wealth, and governance: an agency account. Entrepreneurship Theory and Practice, 39(6), 1281-1303. 